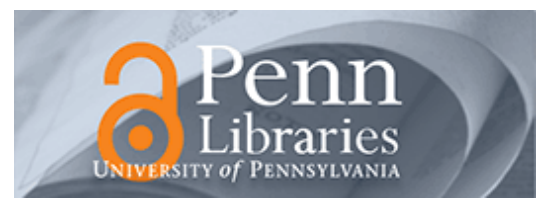

University of Pennsylvania

ScholarlyCommons

Management Papers

Wharton Faculty Research

2-1-2018

\title{
Order in the Court: How Firm Status and Reputation Shape the Outcomes of Employment Discrimination Suits
}

Mary-Hunter McDonnell

University of Pennsylvania

Brayden G. King

Northwestern University

Follow this and additional works at: https://repository.upenn.edu/mgmt_papers

Part of the Management Sciences and Quantitative Methods Commons

\section{Recommended Citation}

McDonnell, M., \& King, B. G. (2018). Order in the Court: How Firm Status and Reputation Shape the Outcomes of Employment Discrimination Suits. American Sociological Review, 83 (1), 61-87.

http://dx.doi.org/10.1177/0003122417747289

This paper is posted at ScholarlyCommons. https://repository.upenn.edu/mgmt_papers/207

For more information, please contact repository@pobox.upenn.edu. 


\title{
Order in the Court: How Firm Status and Reputation Shape the Outcomes of Employment Discrimination Suits
}

\author{
Abstract \\ This article explores the mechanisms by which corporate prestige produces distorted legal outcomes. \\ Drawing on social psychological theories of status, we suggest that prestige influences audience \\ evaluations by shaping expectations, and that its effect will differ depending on whether a firm's \\ blameworthiness has been firmly established. We empirically analyze a unique database of more than \\ 500 employment discrimination suits brought between 1998 and 2008. We find that prestige is \\ associated with a decreased likelihood of being found liable (suggesting a halo effect in assessments of \\ blameworthiness), but with more severe punishments among organizations that are found liable \\ (suggesting a halo tax in administrations of punishment). Our analysis allows us to reconcile two \\ ostensibly contradictory bodies of work on how organizational prestige affects audience evaluations by \\ showing that prestige can be both a benefit and a liability, depending on whether an organization's \\ blameworthiness has been firmly established.
}

\section{Keywords}

status, reputation, deviance, employment discrimination, lawsuits, punishment

\section{Disciplines}

Management Sciences and Quantitative Methods 


\title{
Order in the Court: \\ The Influence of Firm Status and Reputation on the Outcomes of Employment Discrimination Suits
}

\author{
Mary-Hunter McDonnell \\ Assistant Professor of Management \\ The Wharton School \\ The University of Pennsylvania \\ marymcd@wharton.upenn.edu \\ Brayden G. King \\ Professor of Management and Organizations \\ Kellogg School of Management \\ Northwestern University \\ b-king@kellogg.northwestern.edu
}

\begin{abstract}
This paper explores the mechanisms by which corporate prestige produces distorted legal outcomes. Drawing on social psychological theories of status, we suggest that prestige influences audience evaluations by shaping expectations, and that its effect will differ depending on whether a firm's blameworthiness has been firmly established. We empirically analyze a unique database of over 500 employment discrimination suits brought between 1997 and 2008, finding that prestige is associated with a decreased likelihood of being found liable (suggesting a halo effect in assessments of blameworthiness), but with more severe punishments among organizations that are found liable (suggesting a halo tax in administrations of punishment). Our analysis allows us to reconcile two ostensibly contradictory bodies of work on how organizational prestige affect audience evaluations by showing that prestige can be both a benefit and a liability, depending on whether an organization's blameworthiness has been firmly established.

Acknowledgements: The authors would like to thank Joshua Margolis, Mike Pfarrer, Jim Wade, Nathan Miller, and Robert Prentice, as well as participants in seminars at the Wharton School of the University of Pennsylvania, the Academy of Management Annual Meeting in Orlando and the Strategic Society Annual Meeting in Prague, for their helpful comments on earlier versions of this paper.
\end{abstract}

Keywords: reputation, status, work and employment, corporate misconduct, punishment 
Order in the Court: The Influence of Firm Status and Reputation on the Outcomes of Employment Discrimination Suits

Much sociological research has documented the considerable advantages that elite corporations have in achieving favorable outcomes within diverse social domains, including in the policy-making process (Useem, 1984; Mizruchi 2013), the creation of market institutions (Fligstein 2008), and the production of culture (Peterson and Anand 2004). Scholars have offered numerous explanations for business's influence, but one common theme is that societal institutions tend to promote the interest of business due to its prestige in society (e.g., Mizruchi 2004; Kim 2012). When companies occupy positions of prominence, individuals act favorably toward them, even when such behavior might normally elicit negative reactions. In turn, this favorable treatment of business allows corporations to reproduce their advantages and influence. The tendency toward favorable treatment of prominent businesses is partly an extension of the halo effect, or Matthew Effect, propositions (Merton 1968): An organization's prestige, including its high status or good reputation, predisposes audiences to view it favorably, especially in conditions when the quality of its behavior is in question (e.g., Podolny, 1994; Benjamin and Podolny, 1999; Sine, Shane, and Di Gregorio, 2003; Thye 2000; Stuart, Hoang, and Hybels, 1999, Bothner, Podolny, and Smith, 2011; Waguespack and Sorenson 2011; Kim and King 2014).

The subject of disproportionate corporate influence in society merits especial sociological scrutiny because the advantages that the corporate sector enjoys often come at the expense of their employees or communities. Theoretically, legal action against corporations, whether civil or criminal, is meant to operate as an external constraint on corporate power, dissuading antisocial corporate behavior by punishing businesses when they engage in prohibited behavior. 
In this way the law is meant to provide an autonomous, direct means through which society holds business accountable for its actions. However, the legal system's ability to promote prosocial corporate behavior may be undermined by the Matthew Effect, insofar as elite firms are able to garner more favorable outcomes. This possibility is supported by past work finding that elite corporations enjoy considerable influence within the legal domain (Heinz and Laummann, 1982; Shaffer, 2009), and that business litigation generally tends to favor the interests of large or prestigious companies (Hadfield 2005; Brace and Hall 2001; Dunworth and Rogers 1996: 502; Kenworthy et al. 1996). In fact, in one of the earliest sociological treatments of the subject corporate crime, Sutherland (1949) explicitly warned that status within the business sector contributed to distortions in the enforcement of laws as applied to corporate offenders, yet the precise mechanisms through which this distortion occurs remain unclear. Further, research on corporate litigation has to date "devot[ed] next to no attention to distinctions between litigant types" (Hadfield 2005: 1277), which hampers our understanding of why certain corporations seem to receive more favorable treatment than others (Dunworth and Rogers 1996). In this paper, we address these problems by exploring whether and through what mechanisms corporate prestige produces distortive legal outcomes.

Our exploration of the relationship between corporate prestige and legal outcomes provides an additional opportunity to reconcile two ostensibly contradictory bodies of work pertaining to the role of organizational prestige in evaluative settings. The first of these bodies of work, consistent with the Matthew effect proposition, suggests that prestige leads audiences to give organizations the benefit of the doubt in evaluative situations (Dowling, 2002; Fombrun and van Riel, 2003; Davies et al., 2003). For example, stakeholders confronted with charges of deviance typically have greater confidence in reputable organizations (Fombrun, 1996). 
Similarly, organizational status eases regulators' concerns when a company has experienced recent product failures (Kim, 2012), and investors react less negatively to earnings restatements when the firm belongs to a high status industry (Sharkey, 2014).

Interestingly, however, a second body of research supports a contrary proposition that prestige can be a liability to firms in evaluative settings, insofar as it translates at times into increased scrutiny and harsher reactions from stakeholders. For example, the actions of reputable companies are more consistently subject to the scrutiny of their peers and the media (Edelman, 1992; Fombrun, 1996; Pollock, Rindova and Maggitti, 2008), as well as agitated stakeholders (King, 2008; 2011; Briscoe and Safford, 2008; McDonnell and King, 2013; Bartley and Child, 2014; King and McDonnell, 2015). Kovacs and Sharkey (2014) found that books that receive prestigious awards are subsequently rated more negatively by users, suggesting that status markers can produce heightened expectations that can lead to more negative evaluations. Similarly, companies with prestigious CEOs often underperform, partly due to heightened investor expectations (Malmendier and Tate, 2009), and companies with better reputations experience greater market share declines in the wake of product recalls (Rhee and Haunschild, 2006). ${ }^{1}$ In these cases, rather than inducing more favorable evaluations as the Matthew effect would predict, prestige appears to amplify concerns about a company's quality or behavior (Hahl and Zuckerman 2014).

We seek to reconcile these opposing sets of findings by exploring the boundary conditions under which an organization's prestige might shift from a benefit to a liability in the

\footnotetext{
${ }^{1}$ Status research at the individual level also indicates that status may be a liability in certain situations. Graffin et al. (2013), for example, found that high status members of the British Parliament who were implicated in an expense scandal experienced greater pressure from journalists and were consequently more likely to leave the Parliament. And Wheeler et al. (1982) found that the severity of punishment meted out to individuals prosecuted for white collar crime was positively related to their occupational status.
} 
litigation process. Specifically, we propose that the influence of prestige on legal judgments depends on whether a firm's blameworthiness for a charged transgression has been firmly established. Drawing on social psychological theories of status (Berger et al. 1977; Ridgeway 1991; Wagner and Berger 2002; Correll et al. 2007), we claim that prestige influences stakeholder evaluations by shaping expectations (Kim and King, 2014). When an organization is initially accused of deviant behavior but its guilt has not yet been firmly established, a positive reputation or high status will lead evaluators to expect that it behaved appropriately, producing a halo effect that benefits prestigious firms. Once an attribution of guilt or blameworthiness has been established, however, this halo effect no longer holds. At that point, we argue, a positive reputation and high status become a liability, as evaluators balk in response to the violation of their expectations. Evaluators may feel especially duped, jilted, or betrayed when an organization they trust and admire has deviated, which can elicit an especially punitive response: what we call a halo tax. Accordingly, once an attribution of guilt or blameworthiness has attached, we expect evaluators to punish a more prestigious organization more harshly than its peers.

Importantly, in the context of civil litigation, our proposed boundary condition suggests that an organization's prestige is likely to affect legal outcomes differently at different stages of a trial. In the first stage of a trial - the stage in which the jury determines whether or not the company has committed a legally proscribed action -the company's blameworthiness for the charged transgression is still questionable, allowing room for doubt. The plaintiff will provide evidence that the company behaved wrongfully, but the company will provide its own evidence to refute the charge. Under these conditions, the positive expectations associated with having a high status or good reputation ought to benefit the accused company and we should observe a halo effect, such that more prestigious firms will be less likely to be found blameworthy than 
their peers. In the second stage of a trial - the sentencing phase in which the jury determines the appropriate punishment for a transgression- the company has already been found blameworthy. The jury enters the sentencing phase only when the defendant's blameworthiness for the charged transgression has been firmly established, at which point the jury is asked to determine an appropriate punishment. Under these conditions, the positive expectations associated with having high status or a good reputation have been violated, which we expect to lead to a halo tax, such that more prestigious organizations will be allotted harsher punishments than their peers.

We test our hypotheses using a unique archival dataset of jury verdicts from employment discrimination claims filed against a sample of large US companies between 1997 and 2008. We chose employment discrimination as our empirical context because it is a clear example of an organizational transgression, as indicated by highly institutionalized efforts to suppress it, including anti-discrimination laws and ubiquitous sensitivity training programs (Nelson, Berrey, and Nielsen 2008). Legal research has documented that employment discrimination lawsuits are especially difficult to win, partly due to biases held by judges and juries (Selmi 2000), which emphasizes the uncertainty of these proceedings.

Ultimately, our results provide evidence for both the halo effect and the halo tax. In our model predicting the jury's initial assessment of guilt, we find that a firm's status is negatively associated with the likelihood of being deemed blameworthy for employment discrimination. However, in the second stage of litigation, after the company's blameworthiness has been established, we find that a firm's status and its reputation for being a good employer become liabilities. Interestingly, therefore, we find evidence for a halo effect generated by status in an evaluative situation in which the organization's guilt is uncertain and evidence of a halo tax generated by status and context-specific reputation in an evaluative setting in which the 
organization's guilt has been established. We argue that these observed effects can be explained by the benefit (in the former case) and the burden (in the latter) of positive expectations.

Our findings underscore an understudied source of punitive liability faced by companies that do not live up to their audience's positive expectations. Status, we show, can be both an asset and a liability, exhibiting the potential to both protect corporate litigants from attributions of blameworthiness and to expose them to greater punitive action when they transgress. We conclude the paper by discussing the implications of our findings for our theoretical understanding of corporate power in the legal system, as well as for our understanding of how organizational status affects audience evaluations more generally.

\section{Background and Theory Development}

Before delving into an applied analysis of how organizational prestige affects evaluative outcomes, it is necessary to first clarify what we conceptualize as complementary components of prestige: status and reputation (Bitektine, 2011; Sorenson, 2014). Although they are sometimes used interchangeably (Lang and Lang 1988; Rindova et al. 2005; Love and Kraatz 2009; Rindova, Williamson, and Petkova 2010; Lange, Lee, and Dai 2011; McDonnell and King 2013), status and reputation represent distinct forms of esteem. Status refers to the "relative social standing" of an actor (Sorenson, 2014: 63) and usually denotes an actor's position in a hierarchy (Podolny, 2001; Graffin et al., 2013) or social rank (Washington and Zajac, 2004; Bitektine, 2011). Most definitions of status emphasize the positional nature of status, such as a ranking or pattern of deference relations that elevates one organization over another (e.g., Podolny, 2001; Espeland and Sauder, 2007). Reputation, in contrast, refers to shared perceptions of an actor's unique and distinguishing qualities (Fombrun and Shanley 1990; King and Whetten, 2008) and frequently invokes past 
performance (Sorenson, 2014) or comparable differences across actors (Deephouse and Carter, 2005). Reputation, in contrast to status, is multidimensional and can convey a variety of different performance criteria (Rao, 1994; Bitektine, 2011). The same organization can have a positive reputation in one domain, such as product quality (e.g., Rhee and Haunschild, 2003), and yet have a weak or negative reputation in another domain, such as the treatment of employees. ${ }^{2}$

Our contention is that the effect of organizational prestige on evaluative outcomes in legal contexts will shift depending on whether the blameworthiness of the organizational action being judged is uncertain or established. We expect that prestige will lead to halo effects that benefit prestigious firms in evaluative domains where blameworthiness is uncertain, but that prestige will heighten punitive responses in evaluative domains where blameworthiness has been clearly established. Lawsuits in the United States provide a natural setting in which to test this contention because they are bifurcated into two discrete phases which vary in terms of established blameworthiness. In the first phase of a suit, the trial, the jury is asked to determine guilt or liability. During this phase, whether or not the company's actions merit blame is an open question and is therefore uncertain. While the aggrieved party will provide evidence to show that the company's behavior was wrongful or negligent, the company will offer evidence of its innocence. Firms that are found blameworthy in the first stage of the trial then move on to the second stage of the trial: the sentencing. Here, the jury is asked to determine an appropriate punishment. In this second phase, the company's blameworthiness has been established and is therefore certain. Below, we discuss how the enhanced expectations that are triggered by

\footnotetext{
${ }^{2}$ In a review of theoretical work on the reputation construct, Lange et al. (2011) said that researchers tend to think of reputation in one of three ways: 1) as being known, 2) as being known for something, and 3) generalized favorability. While it is certainly true that reputations consist of different dimensions, our purpose is not to offer a new operationalization but rather to note underlying all of these definitions is a belief that organizational reputations consist of shared perceptions about quality and standing.
} 
organizational prestige are likely to influence audience evaluations within these two separate stages of a trial.

\section{The Trial Phase: How Prestige Influences Evaluations Made Under Conditions where Blameworthiness has not been established}

Although status and reputation differ conceptually, they are both thought to confer halo effects. The benefits that come from being associated with a high status position are sometimes treated as equal to the positive outcomes associated with having a good reputation. And, in fact, recent research has demonstrated that actors benefit from having both, especially when they are aligned (Stern, Dukerich, and Zajac, 2014; Kim and King, 2014). Kim and King (2014) argue that the evaluative benefits that come from status and reputation have the same underlying social psychological mechanisms: behavioral expectations. Status characteristics theory and expectations states theory propose that certain qualities are ascribed with status and subsequently shape what evaluators expect from actors who have those qualities (Berger et al., 1977; Ridgeway 1991; Wagner and Berger 2002; Correll et al. 2007). Similarly, an actor's reputation can shape expectations for future performance, inasmuch as an actor becomes known for behaving or performing in a certain way (Raub and Weesie, 1990). Of course, having a good reputation for behaving a certain way will lead audiences to expect positive behavior in that domain, while a bad reputation will have the opposite effect on expectations. As evidence of this, Kim and King (2014) find that high status baseball pitchers and pitchers who have reputations for throwing with great accuracy receive more favorability from umpires than low status pitchers or pitchers who have reputations for being "wild" and inaccurate.

Past scholarship on organizational reputation and status supports the idea that having high status and/or a good reputation elevates an organization's place among its peers and leads 
audiences to endow it with goodwill and positive expectations (e.g., Lange et al. 2011; Rindova, Petkova, and Kotha 2007; McDonnell and King 2013). Research supporting this 'halo effect' typically assumes that having prestige benefits an organization, especially in crisis or controversial situations. Stakeholders are more willing to give a high status or reputable firm the benefit of the doubt when the firm is enmeshed in a sticky situation (e.g., Fombrun, 1996). In particular, high status and positive reputations reduce the extent to which stakeholders attribute responsibility and blameworthiness for a questionable action or situation if there is doubt about the organization's blameworthiness or intentionality. For example, some past research finds that stakeholders are less likely to assign responsibility to a reputable organization for a crisis, such as when an organization's products are found to be harmful or dangerous (Fombrun, 1996; Klein and Dawar, 2004). Other work finds that external stakeholders, including the media, are less likely to criticize a prestigious organization that is enmeshed in a crisis situation when the organization's level of responsibility is in doubt (Balzer and Sulsky, 1992; Coombs, 1999; Ulmer, 2001). Critical stakeholders, like politicians and regulatory agents, are also less likely to cut ties with a high status organization that is accused of bad behavior (McDonnell and Werner, 2016). Stakeholders judging an organization accused of a transgression may be more likely to infer that the action of a prestigious organization stemmed from a positive motive. One experimental study, for example, finds that participants judging a price increase were more inclined to infer that a reputable company had a positive motive, such that the price increase was seen as fair, whereas they were more likely to infer that a less reputable company had a negative motive, such that the price increase was deemed unfair (Campbell, 1999). Applied to the context of employment discrimination trials explored in the present paper, this research suggests that 
juries of cases against high status and reputable companies may be more inclined to believe that the contested corporate action stemmed from innocent, rather than blameworthy, motives.

The halo effect, we argue, derives from the positive expectations that audiences have of high status and reputable organizations. Reputation and status inform the holistic assessments that evaluators make of firms by shaping their expectations of an organization's risk and performance (O'Donnell and Schultz, 2005). The tendency of people to infer less blame and responsibility for an actor's bad action when they have pre-established positive expectations about the actor stems from the psychological phenomena of motivated reasoning. Research on motivated reasoning suggests that people are very reticent to revise their pre-existing expectations (Traut-Mattausch et al., 2004). Because of this, when judging an actor's guilt, people tend to interpret the evidence presented to them in a way that allows them to confirm their priors (Ditto and Lopez, 1992). This bias has been replicated across numerous contexts. For example, Kunda (1987) presented a sample of women with a study that claimed to provide evidence that coffee was harmful to women's health. Those participants who classified themselves as heavy coffee drinkers found the study to be less convincing than women who were not coffee drinkers. In explorations of motivated reasoning within the context of jury decisions, studies have found that decision makers are likely to interpret evidence presented at trial in a way that confirms their preexisting beliefs derived from racial stereotypes (Rachlinski et al., 2009) or initial impressions of the defendant's moral character (Nadler and McDonnell, 2011).

Inasmuch as status and reputation are signals of quality and create behavioral and performance expectations (e.g., Weigelt and Camerer 1988; Fombrun and Shanley, 1990; Sine et al. 2003), organizations that have high status or generally positive reputations create expectations about positive behavior. When the quality or appropriateness of performance is difficult to 
evaluate, observers will fall back on previously held beliefs and expectations about an actor. In turn, these expectations color observers' judgments and inferences when they are faced with evidence of a potential organizational transgression, such that the actions of high status and reputable companies are likely to be interpreted in a more favorable light.

Taken together, this interdisciplinary research suggests that people tasked with evaluating the guilt of organizations accused of transgressions are less likely to deem prestigious organizations as blameworthy. Thus, we expect:

Hypothesis 1a: In the first stage of a trial where a company is charged with a transgression, the defendant firm's status will be negatively associated with the likelihood that it will be found liable.

Hypothesis $1 \mathrm{~b}:$ : In the first stage of a trial where a company is charged with a transgression, the defendant firm's reputation will be negatively associated with the likelihood that it will be found liable.

\section{The Sentencing Phase: How Prestige Influences Evaluations Made Under Conditions when Blameworthiness has been Established}

We suggest that the same positive expectations associated with high status and good reputations can, however, have detrimental effects once the organization's guilt for a transgression has been firmly established. The basis for this 'halo tax' is that positive expectations, when shown to be violated, lead to harsher judgments and more severe penalties. Organizations with high status and positive reputations are held to a higher standard precisely because more is expected of them. When it is proven that they have engaged in actions that do not accord with their proffered image, they are more likely to be pegged a hypocrite, which may provoke an especially punitive response from evaluators (e.g., Harrison, Ashforth, and Corley, 2009).

The scope condition of the halo tax is that an organization's attribution of guilt has previously been established. Once the uncertainty of guilt is overcome and an organization is 
deemed blameworthy, the positive expectations associated with status and reputation can lead evaluators to experience disappointment, feelings of betrayal, and a desire to harshly punish the guilty organization. This is because, in cases where an organization's guilt is firmly established, observers have no choice but to revisit and question their prior beliefs and expectations. This in turn provokes uncomfortable cognitive dissonance that can elicit a more punitive response, as evaluators who previously believed that an organization maintained a high standard of behavior may seek to punish the organization for failing to abide by those very standards. Illustrative of this, King and McDonnell (2015) find that organizations that have greater reputational standing are more likely to be targeted by activist groups when they fail to live up to expected behavioral standards. Similarly, Rhee and Haunschild (2006) find that firms with higher reputations for product quality suffer greater market penalties in response to a product recall.

Psychological research on the inclination to punish suggests that there is a strong relationship between the anger or outrage that is elicited by an offense and the extent to which people are inclined to punish the offender (Bies, 1987; Kahneman, Schkade, and Sunstein, 1998). Demonstrating a phenomenon they coin "betrayal aversion," Koehler and Gershoff (2003) find that people respond more negatively and recommend more severe punishments when a person or entity that they trust behaves in ways that violate their trust. Relatedly, Rosoff (1989) discovered that high status physicians found guilty of "serious deviance" were evaluated more negatively than low status physicians who committed the same crime, and Skolnick and Shaw (1994) found that high status offenders of criminal laws were judged more harshly when the crime was deemed to be related to their profession.

Extended to the organizational setting, social psychological research on betrayal aversion suggests that the transgressions of high status or reputable organizations are especially likely to 
provoke feelings of outrage from their audiences, as audience members may feel duped, jilted, or betrayed given the strong, positive expectations they had for those organizations. This should, in turn, provoke an especially punitive response. Relatedly, Fragale and her coauthors (2009) found that evaluators are more likely to punish high status wrongdoers because they perceive them to be more intentional than lower status transgressors, and therefore more deserving of harsh punishments. Thus, being in a position of prestige is likely to work against organizations once they have been deemed guilty of transgressive behaviors:

Hypothesis 2a: Once an organization has been found guilty of a transgression, evaluators will punish high status organizations more harshly than low status organizations. Hypothesis $2 b$ : Once an organization has been found guilty of a transgression, evaluators will punish organizations with high reputations more harshly than those with low reputations.

\section{Research Setting}

Employment discrimination lawsuits in the United States result when an employee or prior employee of a company alleges that the company treated them adversely (e.g., by firing them, refusing to promote them, or subjecting them to a hostile work environment) because of their membership in a protected class. Federally recognized protected classes include those based on gender, age, disability, religion, race or nationality. This context presents an ideal setting for exploring our theory of the relationship between prestige and legal outcomes for several reasons. First, workplace discrimination represents a highly institutionalized example of organizational misconduct. The United States has formally prohibited discrimination since the passage of Title VII in the 1964 Civil Rights Act (Sutton et al., 1994), which remains the regulatory act that gives discriminated individuals a right to sue their employer for damages. However, discrimination continues to represent a persistent problem in the American workplace; in each of the past three 
years, the US Equal Employment Opportunity Commission reported receiving nearly 100,000 discrimination charges (USEEOC, 2013). Employment discrimination is, therefore, a clear example of misconduct that is nevertheless common enough to enable empirical investigation.

Second, these cases represent an ideal opportunity to study how prestige affects the severity of legal punishment because of the way in which companies are punished for employment discrimination. Organizations that are found liable for illegally discriminating against an employee are punished by having to pay a monetary sum to the employee, referred to as the employee's "damages award." One portion of that sum, the "compensatory damages award," is meant to compensate the injured party for the direct financial or emotional harms that they suffered as a consequence of the discriminatory action. This aspect of damages is legally limited to the wronged individual's real or projected losses established in the evidence (such as the value of their lost salary and benefits), so the jury has little discretion over the amount of compensatory damages awarded. To the contrary, the jury has more discretion to determine a separate portion of the plaintiff's damages, what is called the "punitive damages award" or "exemplary damages award." The punitive damages award reflects a sum that the jury can make the corporation pay for purely punitive reasons. It is an amount meant to punish the defendant and demonstrate society's disapproval for its deviant behavior. This punitive damages award, which can vary extensively from case to case, provides an easily observable and comparable proxy for the severity of audience reactions across different cases of deviance. For this reason, punitive damages have been used in other research exploring the mechanisms that affect the severity of punishment (e.g., Nordgren and McDonnell, 2010).

Finally, the structure of employment discrimination suits makes them especially useful for testing our disparate predictions about the role of prestige in attributions of guilt (when there 
is uncertainty about whether a firm transgressed) versus allotments of punishment (when a firm's deviance has been established). Employment discrimination lawsuits are bifurcated into two discrete phases. The first phase, the trial, determines whether the company is guilty of wrongful employment discrimination. ${ }^{3}$ In the first phase, juries decide whether or not the company's action is blameworthy. While the aggrieved employee will provide evidence to show that the company wrongfully discriminated against them, the company will offer evidence of its innocence. During this first stage of a trial, a company's guilt is not yet certain. While it is possible that some charges of employment discrimination are supported by overwhelming evidence, such that guilt is clearly apparent before a formal declaration by a jury, it is unlikely that such clear-cut cases are represented among our sample of cases that go to trial and are ultimately decided by a jury. We interviewed a prominent corporate defense attorney who explained this, saying:

"There are very high expenses associated with litigating a case through trial, so it is not in the interests of either party to litigate a trial where the outcome of the case is clear. If there is clear and compelling evidence of discrimination, the economic incentives of the defendant are to settle the case, as opposed to waiting for a jury verdict. The cost of a jury verdict is typically greater than a settlement... and precedential consequences of having an adverse judgment that could be applied in future cases strongly push companies to not litigate the case if the evidence is clear. So, really, it is only the hard cases that go to trial."

As this quote illustrates, the cases that typically are litigated before a jury are those where the outcome is difficult to predict, such that the first stage of a trial is one properly characterized

\footnotetext{
${ }^{3}$ Within legal contexts, guilty verdicts are reserved to criminal trials. Employment discrimination is a tort, not a crime, and jury members technically do not decide whether a company is guilty of employment discrimination in the legal sense, but rather whether the company is liable, meaning that the company's negligence is responsible for the losses suffered by the plaintiff. Throughout this paper we use the term "guilty" in its more general, lay sense, denoting that a company is deemed responsible for any deviant action.
} 
as having a considerable degree of uncertainty about whether the actions of the defendant company were in fact deviant.

Firms that are found guilty of discrimination in the first stage of a trial then move on to the second stage of the trial: the sentencing. At this stage, the court holds a separate trial to ascertain the appropriate amount to make the company pay the aggrieved employee. Again, both the employee and the company will present separate evidence to encourage the jury to award an amount that favors them. But importantly, while the jury continues to exercise discretion in determining the appropriate outcome at this stage of the trial, the company's guilt for a deviant action is already established because the jury has already determined that the company did commit an act of illegal employment discrimination. Thus, the deviance of the company's action at this stage of the trial is certain. This dual structure of the employee discrimination trial provides a suitable context to test our theoretical contention that the effect of organizational prestige on audience evaluations will shift depending on whether the organization's deviance has been established.

\section{Methods}

\section{Sample Creation}

To explore the relationship between corporate prestige and legal outcomes, we built a dataset of all employment discrimination cases against any of the 826 unique companies that were surveyed for Fortune's Most Admirable Companies rankings between 1998 and 2008. The Fortune rankings are regularly employed in organizational scholarship as an indicator of a company's prominence in the corporate field (e.g., Fombrun and Shanley 1990; Staw and Epstein 2000; Roberts and Dowling 2002; King 2008; McDonnell and King, 2013). To create the sample each year, Fortune surveyors begin with the Fortune 1,000, from which they select 
the 15 largest firms from each industry. They then collect survey data about these firms from industry executives, directors and analysts. Fortune aggregates the survey results for each company, then assigns each company a reputation score that ranges from 0 to 10 . Fortune ultimately uses this data to create and publish a list of the 50 Most Admired Companies, but our sample includes every company surveyed (including those that were not ultimately selected for the final published list, which we control for separately). Including all surveyed companies provides us with a wide variation of scores. By limiting our analysis to companies that were surveyed for the rankings, we are able to more accurately quantify and compare the relative status of all companies in our analysis. Importantly, however, our sampling strategy does limit the scope of our findings to large firms that are fairly visible, which are likely to have the kind of well-established reputations and status orderings that are perceptible to lay audience members.

To find employment discrimination cases, we searched the Westlaw jury verdicts database for all employment discrimination cases brought against the firms in our sample. This database is a comprehensive legal resource that includes a searchable archive with information on the jury verdicts or outcomes of civil (noncriminal) cases brought in all 50 states and the District of Columbia. Ultimately, we identified a total of 791 employment discrimination cases brought against companies included in the Fortune rankings that were decided between 1998 and 2008. From these, we culled a subset $(n=131)$ that settled out of court and never went to trial, as well as a subset $(n=104)$ that were dismissed by the trial judge for failure to provide a colorable case or for lack of adequate evidence (i.e., dismissal or summary judgment). We ran several robustness checks to ensure that the culling of this subset does not introduce selection bias for our ultimate analysis. Unpaired t-tests of means comparing the firms in the top $50 \%$ of status and domain-specific reputation with the firms in the bottom $50 \%$ yielded no evidence of 
significant differences in the incidence of settlement or dismissal between these two groups. We ran supplemental regressions of the likelihood of settling out of court and of early dismissal, neither of which indicated that a company's reputation or status is significantly associated with either outcome. Unpaired t-tests of means also yielded no evidence of significant differences in the size (assets) or performance (ROA) of the firms that went to trial as compared to those that were omitted from our sample for settling or being dismissed prior to verdict. Of the remaining employment discrimination cases in our sample that went to jury, the company was found liable for discrimination in 297 cases and was deemed not blameworthy in 259, yielding a total sample size of 556 cases.

\section{Dependent Variable}

In our analysis predicting the outcome of the first stage of employment discrimination cases, we use a binary dependent variable that is coded " 1 " if the jury found the company liable for employment discrimination and " 0 " if the company was found not to have engaged in employment discrimination.

We use two separate proxies to capture the extent of punishment in the second stage of an employment discrimination case. First, given that the jury's decision to assess punitive damages is voluntary and to be used only in severe cases where warranted, we employ a binary dependent variable that is coded " 1 " if the jury assessed any punitive damages, and " 0 " if the jury only recommended compensatory damages. Second, recognizing the considerable variation in the amounts of punitive damages assessed, we also capture the punitive damages award as a continuous count variable indicating the amount (in dollars) that the company was made to pay as punishment for its discriminatory action. Data on punitive damages was not publically 
available in 8 of the cases in our sample that ended in a verdict against the company, reducing our sample size for the stage-two analysis to a total of 289 companies.

\section{Independent Variable}

Our measure of organizational status is based on the general score of favorability that firm receives in the Fortune Most Admirable Companies rankings. The Most Admired index is a proxy for overall audience assessments, being founded, in part, on surveys capturing the perceptions of the executives of an organization's peer firms. Each organization included in the list is given a raw score that ranges from 0 to 10 . Inherent in this process are comparisons executives make between peer firms. Each executive is asked to rate the ten largest firms in his or her industry along various dimensions, thus allowing Fortune to make a relative ranking or a positional hierarchy of firms both within and across industries (see, Bermiss, Zajac, and King, 2014 for details about the ranking process). We chose to use the Fortune Most Admired rankings to capture status given that they are 1) positional and 2) convey relative standing of general favorability to an organization, as opposed to the domain-specific judgment of quality associated with reputation (Rhee and Haunschild, 2006; Sorenson, 2014). Although the Fortune rankings are sometimes used as a measure of reputation, we argue that when this is done they typically represent a form of general reputation or reputational ranking that has more in common with status than with domain-specific reputation (e.g., McDonnell and King, 2013; Bermiss et al., 2014). Because the Fortune rankings are collected in the year prior to that in which they are reported, the rankings have a natural one-year lag. Thus, we use each company's score in the rankings published in the same year that the verdict was decided. Given that the raw scores 
exhibit a pronounced right-skew, we transformed the variable used in our models by adding one and taking its natural $\log$.

In contrast to status, reputation scholars have argued that most organizations' reputations rest on a set of specific practices or characteristics that distinguish them from competitors (e.g., King and Whetten, 2008; Lange et al. 2011; Bitektine, 2011). Consider, for example, firms like Body Shop and Starbucks, which have distinguished themselves for embracing progressive, proenvironmental views. Thus we separately examine the effect of domain-specific reputation by utilizing a separate annual Fortune list, the Best Companies to Work For. Unlike the Most Admired rankings, this list is derived from surveys that are targeted at measures of the quality of companies' employee management. Aspects considered in the rankings include job growth, turnover, pay, benefits, health, work-life programs, and diversity. From these annual surveys, Fortune derives and publishes a rank-ordered list of the companies providing the best employee experience, a type of reputation keenly opposed to the employment discrimination actions we explore. To produce a variable of domain-specific reputation that is on a similar scale as our variable for generalized reputation, we divide each company's position in the Best Companies to Work For list by 10, producing a scale that ranges from 0 (not included) to 10 (the top-ranked company). Like the Most Admired rankings, the Best Companies to Work For list exhibits a natural one-year lag, being derived from surveys collected in the prior year. Thus we derive each company's specific reputation from the list published in the same year in which each jury decision was made. Again, we correct for a right-skew in this variable by adding one and taking its natural $\log$.

\section{Control Variables}


To control for the possibility that the degree of punishment will be affected by the degree to which a plaintiff was financially harmed, we include a control for the compensatory damages portion of the verdict. This portion of a verdict is meant to compensate a plaintiff for losses accrued as a direct result of the discrimination. Compensatory damages may include both economic damages (e.g., lost wages) as well as non-economic damages (e.g., emotional pain and suffering). Also, because the severity of a company's transgression is likely to be affected by the number of people who were allegedly harmed by the discriminatory action, we include a control for the total number of plaintiffs. To correct for a right-skew this variable, we transformed it by adding one and taking its natural log.

Because different classes of discrimination may elicit different punitive responses from jury members, we include a dummy for each class of discrimination suit, based on federallyrecognized protected classes. ${ }^{4}$ These include race or nationality discrimination, gender discrimination, age discrimination, disability discrimination, and religious discrimination. Also, to address the possibility that companies may enjoy a "home field advantage" when they face a jury in their own headquarter state, we include a binary variable, home state case, that is coded " 1 " when the case is in the state where a company is headquartered, and " 0 " otherwise. Information on the individual jury members in the case, such as the members' age, gender, or ethnicity, is not publically available in order to protect the anonymity of jurors. For this reason we are unable to control for the demographic composition of individual juries. However, given that jury members are selected from random drawings of local voting populations, we do not expect that jury compositions vary systematically with respect to firm prestige. However,

\footnotetext{
${ }^{4}$ Although many states additionally recognize pregnancy and sexual orientation as separate protected classes, these categories are not recognized uniformly and so are excluded from our analysis.
} 
because legal norms and cultural responses to discrimination may differ by region, we do include fixed effects for the state in which each case was brought.

We additionally control for several characteristics of the firms involved in discrimination trials that may be associated with punishment amounts. To control for each firm's general size and performance, we include controls for logged assets and return on assets. Because firms may also more likely to be accused of employment discrimination when they employ more people, we include an additional control for logged employees. To account for potential within-year factors that might affect jury outcomes, we include fixed effects for the year in which each verdict was decided. And finally, to address the possibility that jury members may have different expectations and responses to discrimination committed by companies in different industries, we include fixed effects for each company's major SIC industry division (i.e., two-digit SIC code) as reported in Compustat.

\section{Model Specification}

We test our hypotheses using a two-stage Heckman selection model. The two-stage model accounts for sample selection problems that may bias the results. The first stage of the model is a probit model predicting the likelihood that a firm charged with employment discrimination will be found liable at trial. The probit regression is appropriate for models with a binary dependent variable. Every case that went to jury was included in this first stage, and we used this stage of the model to test Hypothesis 1. We include an additional variable in this first stage of the model, win ratio for similar suits in prior year, which is used as a selection instrument predicting the likelihood that a company will be found blameworthy. This variable captures the percentage of cases in the same state in the prior year where a company was found liable for the same 
category of discrimination as a given observation (e.g., religious discrimination, racial discrimination, etc).

The first stage probit regression is used to estimate a selection effect coefficient (referred to as the inverse Mills coefficient, or $\lambda$ ) that is included as a control in the second-stage model. Substantively in our model, $\lambda$ represents a proxy for the probability that a firm that is charged with employment discrimination will be deemed blameworthy. As only companies that are guilty enter the punishment phase of a trial, the present research setting forces a lack of observations of the punishment of companies not deemed guilty, which presents a potential selection problem. The $\lambda$ term added to the second-stage equation as a supplemental regressor measures this sample selection effect (Dolton \& Makepeace, 1986; 1987). Heckman selection models are regularly employed in the management literature when selection bias may be a problem (King, 2008; Leiblin, Reuer and Dalsace, 2002). ${ }^{5}$

The second stage of the model includes only firms that have been deemed blameworthy for employment discrimination. Given that the dependent variable is a highly overdispersed count variable, we run the model in three different ways to probe the robustness of the relationship of our independent variables with the punitive damages awarded. All models are run as generalized linear models using Stata's glm command. In the first set of models, we code the dependent variable as a binary variable, coded " 0 " if the jury chose not to award punitive damages, and "1" otherwise. Here, we specify a logit link function with binomial errors. The dependent variable in the second set of models is a log-transformed variable to correct for a

\footnotetext{
${ }^{5}$ There is an additional potential higher-order selection in our data, insofar as not all companies will be charged with discrimination, and the likelihood of being charged may be correlated with a firm's status or reputation. Of course, the most likely predictor of the likelihood of being charged with employment discrimination is whether or not the firm engages in employment discrimination, a variable which we are unable to observe for firms that are never formally charged. Recognizing this, we have limited the scope of our hypotheses to reflect that we expect our results to hold "among organizations accused of deviance," and not among the more general population of firms.
} 
pronounced right skew. Here, we specify an identity link function with Gaussian errors. The dependent variable in the third model is the untransformed count variable. Here, we specify a log-link function with negative binomial errors. ${ }^{6}$ While it is common practice to correct for bias by transforming a skewed count variable, as we do in the second set of models, the final models' employment of a log-link function in a generalized linear model has the advantage of returning predictions directly on the dependent variable's original measured scale, negating the need for back-transformation and simplifying interpretation (e.g., Cox et al., 2008).

Because results within a state are more likely to be correlated than those between states due to localized laws as well as potential regional differences in attitudes toward discrimination, standard errors across all models are clustered by state. We ran separate models where we clustered all standard errors by company, and these models yielded substantially similar results to those reported below. All models were run using Stata 14.0.

\section{Results}

Results from the first-stage models predicting the likelihood that the company was found liable for employment discrimination are shown in Tables 2.

\section{[Insert Table 2 Here]}

Our control variables yield several interesting findings. Consistent across all models, we find that larger firms (in terms of logged assets) are less likely to be found liable than smaller firms. Model 4 suggests that better performing firms are also less likely to be found liable. Firms are also more likely to be deemed blameworthy in cases with more plaintiffs, where more people are claiming that they were similarly discriminated against at once. Each of these

\footnotetext{
${ }^{6}$ We additionally ran GLM models with the raw continuous dependent variable and a gamma errors. The results of these models were virtually identical to those employing negative binomial errors.
} 
findings is likely in part reflective of the relative resources that either party in the case has at their disposal. Additionally, insofar as juries are more likely to believe that a company discriminated when claims to that effect are made by more than one person, the number of plaintiffs may also represent a proxy for the general strength of the case. Our results also suggest that the companies in our sample were least likely to be found liable in cases alleging racial discrimination.

In support of hypothesis 1, Models 2 and 4 demonstrate a statistically significant and negative relationship between a firm's status and the likelihood of it being found liable for employment discrimination. High status companies, as indicated by their position in the Fortune Most Admired list, are less likely to be deemed blameworthy when charged with discrimination. Specifically, post-estimation margins analysis of Model 4 suggests that a 1 standard deviation increase in status above the mean have around a $10 \%$ lower probability of being found liable in a discrimination trial than firms with a status score at 1 standard deviation below the mean. However, we find no evidence that a company's reputation as a good employer, as indicated by its position in the Best Companies to Work For ranking, is related to the likelihood of liability. This suggests that holistic, generalized signals of prestige such as status may carry more weight for evaluations of corporate conduct in ambiguous situations than do domain-specific indicators of prestige like context-specific reputations.

Results for the second-stage models predicting the extent of punitive damages are shown in Table 3. In this second stage of litigation - once an organization's blameworthiness has been established -- we find that organizational prestige becomes a liability, in support of hypothesis 2 . Here, Models 1 and 2 provide evidence that a firm's status and domain-specific reputation are each positively associated with the likelihood that a jury will require it to pay punitive damages. 
When status and reputation are considered together in Model 3, the effect holds for domainspecific reputation but the effect of status is only marginally significant $(\mathrm{p}=0.05)$.

Models 4-9 provide robust evidence that status and domain-specific reputation also affect the amount of punitive damages that the jury assigns. Notably, the effects of status and reputation on punitive damages are net of the effects of firm size and profitability. Postestimation margins analysis of Model 9 indicates that a firm with status at one standard deviation below the mean would pay a predicted value of $\$ 1,316,968$ in punitive damages, whereas a firm with status at one standard deviation above the mean would pay $\$ 3,095,727$. We also find evidence that a firm's domain-specific reputation leads to separate and independent punitive repercussions. A firm with a domain-specific reputation at one standard deviation below the mean would pay a predicted value of $\$ 1,278,185$, whereas a firm with a domain-specific reputation at one standard deviation above the mean would pay $\$ 3,556,428$ in punitive damages. Thus, we find that only an organization's status generates a halo effect during the first stage of litigation, but in second stage, when blameworthiness has been unambiguously established, both high status and domain-specific reputation can provoke a halo tax. We discuss the theoretical implications of these findings below.

[Insert Table 3 Here]

\section{Discussion and Conclusion}

Many observers, including sociologists, have argued that corporations receive deferential treatment in society. One of the arenas in which favoritism plays out is the legal domain (Nielsen, Nelson, and Lancaster 2010). In the United States, legal intervention - such as lawsuits - is a primary mechanism through which employee discrimination laws are enforced, and yet past research shows that legal means are often quite ineffective at improving workplace 
conditions for the underrepresented (Kalev and Dobbin 2006; Hirsh 2009). One key reason for this seems to be that prestigious companies are less likely to be found liable when discrimination charges are brought against them. Interestingly, we also found that larger and higher performing firms are also less likely to be found liable.

Our analysis confirms that the legal arena is a not an even playing field. The most powerful firms - larger, more profitable, more prestigious companies - are more likely to avoid sanctioning by courts when charged with discrimination. Those companies that tend to receive less favorable treatment, ironically, are the companies likely to do less damage due to their smaller scope and less visible positions in society. Our findings, then, indicate that the favorable treatment of corporations in society is particularly slanted toward those companies that need less favorable treatment due to their size, performance, and prestige.

However, our analysis provides a twist to the story of corporate legal favorability. Although prestigious firms are less likely to be found liable of discrimination charges, once juries rule against them and find them blameworthy, those firms are punished more harshly for their wrongdoing. In the case of employment discrimination suits, we see that courts assign greater punitive damages to more prestigious companies.

We assert that the same social psychological mechanism underlies both phenomena: expectations associated with status and reputation. Because juries have high expectations of prestigious firms and are motivated to see behavior that matches those expectations, prestigious companies are initially treated more favorably, but once those expectations have been demonstrably violated, juries turn against them. The former process, which is grounded in aligning judgments with expectations, is commonly referred to as the halo effect and is thought 
to underlie the Matthew Effect (e.g., Kim and King 2015). We refer to the latter process, which is driven by a violation of expectations, as the halo tax.

Our analysis also produced one unexpected finding: although an organization's status led to both a halo effect when juries assessed blameworthiness and a halo tax after blame was established, a firm's reputation only seemed to increase the extent to which the firm experienced a halo tax at the punitive stage. Why would this be the case? Although we did not hypothesize the difference in effects, we can speculate. One reason for the divergent effect may be that juries are simply less aware of a firm's domain-specific reputation than they are of the company's overarching status. Recognizable, admired companies benefit from a generalized perception of status that is shared by the broader public. Reputations, in contrast, tend to be local and especially known by insiders. Therefore, an employee of a particular industry might be aware of a company's high standards of employment, but this same knowledge is not shared by the general public. Thus, a member of a jury might be unaware that a company is known for being an especially good employer. However, once the company has been found blameworthy for employee discrimination, its prior reputation as a good employer becomes critical evidence to be used by the plaintiff's attorneys in establishing cause for greater punishment. Thus, a firm's domain-specific reputation as a good employer may become more commonly known by juries at the punishment stage than it was at the guilt attribution stage. By implication, status is such a powerful heuristic in evaluative settings because it is "common knowledge" that does not need to be brought to a jury's attention (Chwe, 2013).

The findings of our analysis have several important theoretical implications. First, we argue that the results help resolve a contradiction in the literature on organizational status and reputation. On the one hand, reputation and status should protect a firm from outside scrutiny, 
inasmuch as the halo effect predisposes audiences to give reputable firms the benefit of the doubt. On the other hand, audiences are more likely to attend to controversies involving high status or reputable firms, and might judge them more harshly, given that the firm is not meeting audience members' high expectations for its behavior. Our study attempts to reconcile this contradiction in the empirical literature on organizational prestige and provide a theoretical explanation for the conditions that underlie the halo effect and the halo tax.

We argue that positive expectations associated with prestige benefits organizations (and other actors as well) when there is uncertainty about their guilt in potential wrongdoing, but when that uncertainty has been resolved and there is no room for doubt as to whether a transgression has occurred, the positive expectations associated with prestige turn into a liability. Demonstrable violations of positive expectations lead audiences to more harshly punish high status actors than their peers that have been shown to be guilty of similar wrongdoings.

Second, our findings provide several unique insights for the sociology of law, particularly as pertains to corporate power over legal outcomes and the effectiveness of the legal system to address discrimination. Contributing to research on the social construction of organizational misconduct (Greve, Palmer, and Pozner, 2011), our study provides evidence that reputation plays an important role in processes of labeling and punishing organizational misconduct. In labeling processes, where social-control agents are tasked with categorizing actions as either transgressive or allowed, our findings suggest that organizational prestige may incline evaluators to interpret ambiguous actions as appropriate, rather than deviant. This is likely to be especially impactful for actions at the margins of misconduct, where prestigious companies may be given more leeway engage in actions that would raise a red flag for other companies. It is also likely to be especially impactful in more ambiguous situations where information is sparse and actions are 
less observable, when evaluators are likely to place greater weight on a firm's status as a heuristic device. Thus, prestigious firms may be freer to cross normative boundaries in contexts characterized by a lack of monitoring and transparency. In punitive processes, however, once deviance is clear, our results suggest that prestige works as an aggravating factor that is likely to provoke more severe reactions from evaluators, especially where an organization had a positive reputation in the precise domain in which it has deviated. These findings complement those of Graffin, Bundy, Porac, Wade, and Quinn (2013), who found that elite British members of parliament implicated in the 2009 expense scandal were more likely to be ousted from their positions than their peers after expense records were unexpectedly disclosed by the press. Similarly to the adverse reactions that these individuals faced when their deviance was disclosed and readily decipherable, our findings suggest that organizational evaluators are motivated to punish prestigious firms more harshly than their peers when a transgression has been clearly established.

The findings explain, in particular, one reason why employment discrimination litigation has not been especially effective in promoting more integrated workplaces. Although the purpose of legal interventions like lawsuits are to deter companies from engaging in workplace discrimination, if prestigious firms recognize that they have an advantage in the courts, then the deterrent will lose some of its impact. Lacking consistent monitoring and transparency, firms may see the possibility of punitive damages, even if they are relatively greater for the most prestigious firms, as a risk worth taking. Thus, despite the reality of a halo tax once a liability of discrimination has been established, firms realize that they enter the judicial process in an uneven playing field that dramatically favors them. Our study demonstrates just how favorable discrimination litigation actually is for large, prestigious companies. 
Finally, from a policy perspective, the increased severity of punishment for high-status and reputable firms may function as a necessary deterrent, given recent findings that actors within reputable firms are more likely to transgress legal boundaries (Mishina, Dykes, Block, and Pollock, 2010). Indeed, it may be especially critical to deter the deviance of prestigious firms, given the extensive damage that transgressions by trusted organizations can do to stakeholder confidence. Prior research suggests that reputable firms that violate normative expectations spread legitimacy losses far beyond their isolated transgression, shaking stakeholders' confidence in business partners and other innocent firms in their industry (Jensen, 2006; Jonsson, Greve and Fujiwara-Greve, 2009). By punishing reputable and high status companies more severely when they transgress, the halo tax observed in this paper may more effectively deter prestigious organizations from future transgressions. In so doing, the halo tax may serve as mechanism of reputational fitness that operates ex post to keep reputable companies honest by discouraging them from straying from the positive behavioral expectations that stakeholders hold for them. 
Table 1: Summary Statistics and Correlation Matrix

\begin{tabular}{|c|c|c|c|c|c|c|c|c|c|c|c|}
\hline & Variable & Mean & S.D. & Min & Max & 1 & 2 & 3 & 4 & 5 & 6 \\
\hline & Liable & 0.534 & 0.50 & 0.00 & 1.00 & & & & & & \\
\hline & Previous Win Ratio for Similar Suits & 0.480 & 0.23 & 0.00 & 1.00 & -0.04 & & & & & \\
\hline & Punitive Damages (Binary) & 0.471 & 0.50 & 0.00 & 1.00 & & -0.05 & & & & \\
\hline & Status (Logged) & 1.467 & 0.91 & 0.00 & 2.31 & -0.07 & 0.06 & 0.09 & 0.11 & & \\
\hline & Reputation (Logged) & 0.148 & 0.42 & 0.00 & 2.20 & 0.04 & 0.10 & 0.10 & 0.14 & 0.12 & \\
\hline & Compensatory Damages (Logged) & 12.151 & 2.60 & 0.00 & 16.21 & & -0.08 & -0.17 & 0.11 & 0.02 & -0.07 \\
\hline & Employees (Logged) & 4.668 & 1.38 & -1.53 & 7.65 & -0.05 & 0.05 & 0.06 & 0.09 & 0.33 & 0.27 \\
\hline & Number of Plaintiffs (Logged) & 0.714 & 0.14 & 0.00 & 2.40 & 0.09 & 0.02 & 0.01 & 0.11 & 0.00 & -0.03 \\
\hline 11 & Home State Case & 0.171 & 0.38 & 0.00 & 1.00 & -0.14 & -0.05 & -0.05 & -0.02 & 0.01 & 0.01 \\
\hline & Disc Cat: Racial & 0.326 & 0.47 & 0.00 & 1.00 & -0.10 & -0.13 & 0.07 & -0.02 & -0.05 & -0.05 \\
\hline & Disc Cat: Disability & 0.227 & 0.42 & 0.00 & 1.00 & 0.02 & 0.04 & -0.11 & -0.08 & -0.01 & 0.05 \\
\hline 14 & Disc Cat: Age & 0.223 & 0.42 & 0.00 & 1.00 & 0.03 & 0.15 & -0.16 & -0.02 & 0.04 & -0.09 \\
\hline & & & & & & & & & & & \\
\hline & & 7 & 8 & 9 & 10 & 11 & 12 & 13 & 14 & 15 & \\
\hline & Log Assets & 0.09 & & & & & & & & & \\
\hline & Log Employees & -0.06 & 0.60 & & & & & & & & \\
\hline & Log \# Plaintiffs & -0.11 & -0.06 & 0.01 & & & & & & & \\
\hline & Home State Case & 0.00 & -0.07 & -0.21 & -0.01 & & & & & & \\
\hline 12 & Disc Cat: Racial & 0.00 & -0.08 & -0.06 & 0.14 & 0.03 & & & & & \\
\hline 13 & Disc Cat: Disability & -0.04 & -0.04 & 0.00 & -0.08 & 0.04 & -0.32 & & & & \\
\hline 14 & Disc Cat: Age & 0.10 & 0.14 & -0.02 & 0.00 & 0.03 & -0.25 & -0.10 & & & \\
\hline 15 & Disc Cat: Gender & -0.08 & 0.03 & 0.02 & -0.03 & -0.04 & -0.36 & -0.24 & -0.18 & & \\
\hline 16 & Appeared in FMAC List & -0.08 & 0.27 & 0.43 & 0.01 & 0.03 & 0.00 & 0.02 & -0.06 & 0.03 & \\
\hline
\end{tabular}


Table 2: Probit Regression Predicting the Likelihood of being found Liable in Cases of Alleged Employment Discrimination, 1998-2008.

\begin{tabular}{|c|c|c|c|c|}
\hline VARIABLES & Model 1 & Model 2 & Model 3 & Model 4 \\
\hline Status & & $\begin{array}{c}-0.157 * \\
(0.07)\end{array}$ & & $\begin{array}{c}-0.148^{*} \\
(0.07)\end{array}$ \\
\hline Reputation & & & $\begin{array}{l}0.313 \\
(0.26)\end{array}$ & $\begin{array}{l}0.295 \\
(0.26)\end{array}$ \\
\hline Prev Win Ratio for Similar Suits & $\begin{array}{c}-0.696 * * \\
(0.25)\end{array}$ & $\begin{array}{c}-0.674 * * \\
(0.26)\end{array}$ & $\begin{array}{c}-0.655^{*} \\
(0.26)\end{array}$ & $\begin{array}{c}-0.640^{*} \\
(0.26)\end{array}$ \\
\hline Log Assets & $\begin{array}{c}-0.193 * * \\
(0.07)\end{array}$ & $\begin{array}{c}-0.166^{* *} \\
(0.06)\end{array}$ & $\begin{array}{c}-0.179 * * \\
(0.07)\end{array}$ & $\begin{array}{c}-0.155^{*} \\
(0.07)\end{array}$ \\
\hline Log Employees & $\begin{array}{c}0.09 \\
(0.09)\end{array}$ & $\begin{array}{l}0.082 \\
(0.09)\end{array}$ & $\begin{array}{l}0.067 \\
(0.09)\end{array}$ & $\begin{array}{l}0.062 \\
(0.09)\end{array}$ \\
\hline ROA & $\begin{array}{l}-2.695 \\
(1.66)\end{array}$ & $\begin{array}{c}-2.862+ \\
(1.65)\end{array}$ & $\begin{array}{c}-3.114+ \\
(1.64)\end{array}$ & $\begin{array}{c}-3.242 * \\
(1.63)\end{array}$ \\
\hline Log \# Plaintiffs & $\begin{array}{c}1.333^{* * *} \\
(0.46)\end{array}$ & $\begin{array}{c}1.433^{* *} \\
(0.52)\end{array}$ & $\begin{array}{c}1.363 * * * \\
(0.41)\end{array}$ & $\begin{array}{c}1.450 * * \\
(0.47)\end{array}$ \\
\hline Home State Case & $\begin{array}{c}-0.250 \\
(0.18)\end{array}$ & $\begin{array}{l}-0.233 \\
(0.17)\end{array}$ & $\begin{array}{l}-0.241 \\
(0.18)\end{array}$ & $\begin{array}{c}-0.226 \\
(0.18)\end{array}$ \\
\hline Disc. Cat: Racial & $\begin{array}{c}-0.375 * * \\
(0.13)\end{array}$ & $\begin{array}{c}-0.384 * * \\
(0.13)\end{array}$ & $\begin{array}{c}-0.347 * * \\
(0.12)\end{array}$ & $\begin{array}{c}-0.358 * * \\
(0.12)\end{array}$ \\
\hline Disc. Cat: Gender & $\begin{array}{r}-0.041 \\
(0.12)\end{array}$ & $\begin{array}{l}-0.049 \\
(0.12)\end{array}$ & $\begin{array}{r}-0.022 \\
(0.12)\end{array}$ & $\begin{array}{l}-0.031 \\
(0.12)\end{array}$ \\
\hline Disc. Cat: Disability & $\begin{array}{l}0.041 \\
(0.11)\end{array}$ & $\begin{array}{l}0.043 \\
(0.12)\end{array}$ & $\begin{array}{l}0.048 \\
(0.11)\end{array}$ & $\begin{array}{l}0.049 \\
(0.12)\end{array}$ \\
\hline Disc. Cat: Age & $\begin{array}{l}0.088 \\
(0.11)\end{array}$ & $\begin{array}{l}0.104 \\
(0.11)\end{array}$ & $\begin{array}{l}0.113 \\
(0.11)\end{array}$ & $\begin{array}{l}0.126 \\
(0.11)\end{array}$ \\
\hline Appeared in FMAC List & $\begin{array}{l}-0.020 \\
(0.20) \\
(0.25)\end{array}$ & $\begin{array}{l}0.116 \\
(0.20) \\
(0.25)\end{array}$ & $\begin{array}{l}-0.091 \\
(0.23) \\
(0.25)\end{array}$ & $\begin{array}{l}0.041 \\
(0.22) \\
(0.25)\end{array}$ \\
\hline Annual Fixed Effects & Yes & Yes & Yes & Yes \\
\hline State Fixed Effects & Yes & Yes & Yes & Yes \\
\hline Industry Fixed Effects & Yes & Yes & Yes & Yes \\
\hline Constant & $\begin{array}{l}1.352 \\
(0.78)\end{array}$ & $\begin{array}{l}1.217 \\
(0.80)\end{array}$ & $\begin{array}{l}1.314 \\
(0.76)\end{array}$ & $\begin{array}{l}1.196 \\
(0.77)\end{array}$ \\
\hline $\begin{array}{l}\text { Observations } \\
\text { Log Pseudolikelihood } \\
\text { Pseudo } R^{\wedge} 2\end{array}$ & $\begin{array}{c}556 \\
-333.62 \\
0.13\end{array}$ & $\begin{array}{c}556 \\
-331.78 \\
0.14\end{array}$ & $\begin{array}{c}556 \\
-331.83 \\
0.14\end{array}$ & $\begin{array}{c}556 \\
-330.2 \\
0.14\end{array}$ \\
\hline
\end{tabular}

Robust standard errors, clustered by state, in parentheses. The omitted comparison category for types of discrimination cases is religious discrimination.

$* \mathrm{p}<0.05, * * \mathrm{p}<0.01, * * * \mathrm{p}<0.001$ 
Table 3: Generalized Linear Models of Punitive Damages Levied Against Companies Found Liable for Employment Discrimination, 1998-2008.

\begin{tabular}{|c|c|c|c|c|c|c|c|c|c|}
\hline \multirow[b]{2}{*}{ VARIABLES } & \multicolumn{3}{|c|}{$\begin{array}{c}\text { Binary Punitive Damages } \\
\text { Award (Logit Link Function, } \\
\text { Gaussian Errors) }\end{array}$} & \multicolumn{3}{|c|}{$\begin{array}{l}\text { Logged Punitive Damages } \\
\text { Award (Identity Link } \\
\text { Function, Gaussian Errors) }\end{array}$} & \multicolumn{3}{|c|}{$\begin{array}{c}\text { Punitive Damages Award (In } \\
\text { Dollars) (Log Link Function. } \\
\text { Negative Binomial Errors) }\end{array}$} \\
\hline & Model 1 & Model 2 & Model 3 & Model 4 & Model 5 & Model 6 & Model 7 & Model 8 & Model 9 \\
\hline \multirow[t]{2}{*}{ Status } & $0.362^{*}$ & & 0.334 & $1.119^{*}$ & & $0.989^{*}$ & $0.562^{*}$ & & $0.475^{*}$ \\
\hline & $(0.17)$ & & $(0.17)$ & $(0.47)$ & & $(0.47)$ & $(0.24)$ & & $(0.23)$ \\
\hline \multirow[t]{2}{*}{ Reputation } & & $0.654^{*}$ & $0.607 *$ & & $2.309 * *$ & $2.108^{*}$ & & $1.104 * *$ & $1.003^{* *}$ \\
\hline & & $(0.29)$ & $(0.30)$ & & $(0.86)$ & $(0.89)$ & & $(0.39)$ & $(0.38)$ \\
\hline \multirow[t]{2}{*}{ Log Comp. Damages } & $-0.111^{*}$ & $-0.104 *$ & $-0.115^{*}$ & -0.197 & -0.188 & -0.209 & $0.079 *$ & 0.080 & 0.062 \\
\hline & $(0.06)$ & $(0.05)$ & $(0.05)$ & $(0.14)$ & $(0.14)$ & $(0.14)$ & $(0.04)$ & $(0.05)$ & $(0.04)$ \\
\hline \multirow[t]{2}{*}{ Log Assets } & -0.061 & -0.157 & -0.111 & -0.097 & -0.401 & -0.265 & 0.180 & -0.234 & -0.076 \\
\hline & $(0.20)$ & (0.19) & (0.19) & $(0.53)$ & $(0.48)$ & $(0.49)$ & $(0.21)$ & $(0.26)$ & $(0.22)$ \\
\hline \multirow[t]{2}{*}{ Log Employees } & 0.108 & 0.132 & 0.114 & 0.267 & 0.334 & 0.263 & 0.199 & 0.380 & 0.289 \\
\hline & $(0.27)$ & $(0.27)$ & $(0.26)$ & $(0.75)$ & $(0.73)$ & $(0.72)$ & $(0.29)$ & $(0.28)$ & $(0.28)$ \\
\hline \multirow[t]{2}{*}{ ROA } & -1.734 & -2.188 & -2.151 & -5.184 & -7.029 & -6.738 & 1.695 & -1.561 & -0.505 \\
\hline & $(3.43)$ & (3.54) & (3.43) & $(9.42)$ & $(9.70)$ & $(9.45)$ & $(3.44)$ & $(3.06)$ & (3.83) \\
\hline \multirow[t]{2}{*}{ Log Number of Plaintiffs } & 0.048 & 1.152 & 0.565 & 1.345 & 4.887 & 3.097 & $3.332 *$ & $5.679 * * *$ & $4.812 * *$ \\
\hline & (1.39) & (1.29) & (1.38) & $(3.77)$ & $(3.26)$ & (3.59) & $(1.31)$ & $(1.69)$ & $(1.51)$ \\
\hline \multirow[t]{2}{*}{ Home State Case } & 0.043 & -0.272 & -0.079 & 0.243 & -0.868 & -0.308 & 1.808 & 0.891 & 1.274 \\
\hline & $(0.57)$ & $(0.55)$ & $(0.58)$ & $(1.59)$ & $(1.55)$ & $(1.58)$ & $(1.16)$ & $(1.28)$ & $(1.17)$ \\
\hline \multirow[t]{2}{*}{ Appeared in FMAC List } & -0.309 & -0.260 & -0.469 & -0.519 & -0.479 & -1.035 & 0.134 & 0.087 & -0.194 \\
\hline & $(0.50)$ & $(0.49)$ & $(0.52)$ & $(1.32)$ & (1.34) & $(1.36)$ & $(0.63)$ & $(0.60)$ & $(0.66)$ \\
\hline \multirow[t]{2}{*}{ Disc. Category: Racial } & 0.090 & -0.323 & -0.056 & 0.166 & -1.139 & -0.362 & -0.595 & $-1.592 * *$ & $-1.036^{*}$ \\
\hline & $(0.47)$ & $(0.43)$ & $(0.47)$ & $(1.35)$ & $(1.17)$ & $(1.29)$ & $(0.51)$ & $(0.53)$ & $(0.50)$ \\
\hline \multirow[t]{2}{*}{ Disc. Category: Dis ability } & $-0.806^{*}$ & $-0.766^{*}$ & $-0.773 *$ & $-2.435 * *$ & $-2.337 *$ & $-2.356 * *$ & -1.307 & -1.354 & -1.321 \\
\hline & $(0.32)$ & $(0.31)$ & $(0.31)$ & $(0.94)$ & $(0.91)$ & $(0.90)$ & $(0.75)$ & $(0.76)$ & $(0.70)$ \\
\hline \multirow[t]{2}{*}{ Disc. Category: Age } & $-0.974 *$ & $-0.926^{*}$ & $-0.958^{*}$ & $-2.765^{*}$ & $-2.584 *$ & $-2.674 *$ & -1.114 & -0.577 & -0.881 \\
\hline & $(0.46)$ & $(0.46)$ & $(0.48)$ & $(1.18)$ & $(1.18)$ & $(1.21)$ & $(0.68)$ & $(0.61)$ & $(0.71)$ \\
\hline \multirow[t]{2}{*}{ Disc. Category: Gender } & -0.102 & -0.195 & -0.153 & -0.527 & -0.823 & -0.705 & -0.701 & -0.931 & -0.711 \\
\hline & $(0.48)$ & $(0.45)$ & $(0.47)$ & $(1.35)$ & $(1.27)$ & $(1.30)$ & $(0.57)$ & $(0.55)$ & $(0.54)$ \\
\hline \multirow[t]{2}{*}{ Inverse Mills Ratio } & -0.330 & 1.280 & 0.344 & -1.159 & 4.070 & 1.233 & -1.047 & 2.764 & 0.948 \\
\hline & $(1.21)$ & (1.09) & $(1.22)$ & $(3.43)$ & $(2.89)$ & (3.39) & $(1.63)$ & $(1.57)$ & $(1.62)$ \\
\hline Annual Fixed Effects & Yes & Yes & Yes & Yes & Yes & Yes & Yes & Yes & Yes \\
\hline State Fixed Effects & Yes & Yes & Yes & Yes & Yes & Yes & Yes & Yes & Yes \\
\hline Industry Fixed Effects & Yes & Yes & Yes & Yes & Yes & Yes & Yes & Yes & Yes \\
\hline \multirow[t]{2}{*}{ Constant } & 1.852 & 1.601 & 1.861 & 9.618 & 8.99 & 9.688 & $8.937 * * *$ & $9.554 * * *$ & $9.626^{* * *}$ \\
\hline & (2.19) & $(2.02)$ & $(2.10)$ & (6.19) & $(5.87)$ & $(6.08)$ & $(2.16)$ & $(2.10)$ & $(2.15)$ \\
\hline Observations & 289 & 289 & 289 & 289 & 289 & 289 & 289 & 289 & 289 \\
\hline Log Pseudolikelihood & -174.95 & -174.98 & -173.76 & -936.96 & -936.45 & -935.13 & -4068.12 & -4063.69 & -4058.37 \\
\hline
\end{tabular}

Robust standard errors, clustered by state, in parentheses. The omitted comparison category for types of discrimination cases is religious discrimination.

$* \mathrm{p}<0.05, * * \mathrm{p}<0.01, * * * \mathrm{p}<0.001$ 


\section{Works Cited}

Balzer, WK, Sulsky, LM. 1992. "Halo and performance appraisal research: A critical examination." Journal of Applied Psychology, 77: 975-985.

Bartley, Tim and Curtis Child. 2014. "Shaming the Corporation: The Social Production of Targets and the Anti-Sweatshop Movement." American Sociological Review 79:653-679.

Benjamin, B. A. and J. M. Podolny. 1999. "Status, quality, and social order in the California wine industry." Administrative Science Quarterly 44:563-589.

Berger, Joseph M., M. Hamit Fisek, Robert Z. Norman, and Morris Zelditch, Jr. 1977. Status Characteristics and Social Interaction: An Expectation States Approach, Edited by Anonymous. New York: Elsevier.

Bermiss, YS, Zajac, EJ, King, BG (2014). "Under construction: How commensuration and management fashion affect corporate reputation rankings." Organization Science, 25: 591-608.

Bies, RJ. 1987. "The predicament of injustice: The management of moral outrage." Research in Organizational Behavior, 9: 289-319.

Bitektine, A 2011. "Toward a theory of social judgements of organizations: The case of legitimacy, reputation, and status." Academy of Management Review, 36: 151-179.

Bothner, Matthew S, Joel M Podolny, and Edward Bishop Smith. 2011. "Organizing contests for status: The Matthew effect vs. the Mark effect." Management Science 57:439-457.

Brace, Paul and Melinda Gann Hall. 2001. "" Haves" versus" have nots" in state Supreme Courts: Allocating docket space and wins in power asymmetric cases." Law and Society Review:393-417.

Briscoe, F, Safford, S. 2008. "The Nixon-in-China effect: Activism, imitation and the institutionalization of contentious practices." Administrative Science Quarterly, 53: 460-491.

Campbell, MC. 1999. "Perceptions of price unfairness: Antecedents and consequences." Journal of Marketing Research, 36: 187-199.

Chwe, M. S.-Y. 2013. Rational ritual: Culture, coordination, and common knowledge: Princeton University Press.

Coombs, WT. 1999. Ongoing crisis communication: Planning, managing, and responding. Los Angeles: Sage.

Correll, S. J., S. Benard, and I. Paik. 2007. "Getting a job: Is there a motherhood penalty?" American Journal of Sociology 112:1297-1338. 
Cox, N.J., Warburton, J., Armstrong, A., and Holliday, V.J. 2008. "Fitting concentration and load rating curves with generalized linear models." Earth Surface Processes and Landforms, 33:25-39.

Davies, G, Chun, R, da Silva, RV, Roper, S. 2003. Corporate Reputation and Competitiveness, Routledge, New York, NY.

Deephouse, DL, Carter, SM. 2005. "An examination of differences between organizational legitimacy and organizational reputation.” Journal of Management Studies, 42: 329-360.

Ditto, PH, Lopez, DF. 1992. "Motivated skepticism: Use of differential decision criteria for preferred and nonpreferred conclusions." Journal of Personality and Social Psychology, 568.

Dolton, PJ, Makepeace, H. 1986. "Sample selection and male-female earnings differentials in the graduate labour market." Oxford Economic Papers, Oxford University Press, 38:317-41.

Dolton, PJ, Makepeace, H. 1987. "Interpreting sample selection effects," Economics Letters, Elsevier, 24:373-379.

Dowling, G. 2002. Creating Corporate Reputations: Identity, Image, and Performance, Oxford University Press, New York, NY.

Dunworth, Terence and Joel Rogers. 1996. "Corporations in court: Big Business litigation in US federal courts, 1971-1991." Law \& Social Inquiry 21:497-592.

Edelman, LB. 1992. "Legal ambiguity and symbolic structures: Organizational mediation of civil rights law.” American Journal of Sociology, 97: 1531-1576.

Espeland WN, Sauder, M. 2007. "Ratings and reactivity: How public measures recreate social worlds." American Journal of Sociology, 113: 1-40.

Fligstein, Neil. 2008. Euroclash: The EU, European identity, and the future of Europe: Oxford University Press.

Fombrun, CJ, Shanley, M. 1990. "What's in a name? Reputation building and corporate strategy." Academy of Management Journal, 33: 233-258.

Fombrun, CJ. 1996. Reputation: Realizing Value from the Corporate Image. Cambridge, MA: Harvard Business School Press.

Fombrun, CJ, van Riel, CBM. 2003. Fame \& Fortune: How Successful Companies Build Winning Reputations, Prentice-Hall Financial Times, New York, NY.

Fragale, A. R., Rosen, B., Xu, C., \& Merideth, I. 2009. "The higher they are, the harder they fall: The effects of wrongdoer status on observer punishment recommendations and intentionality attributions." Organizational Behavior and Human Decision Processes, 108(1): 53-65. 
Graffin, SD., Bundy, J, Porac, JF, Wade, JB, Quinn, DP. 2013. "Falls from grace and the hazards of high status: The 2009 British MP expense scandal and its impacts on parliamentary elites." Administrative Science Quarterly, 58: 313-345.

Greve, HR, Palmer, D, Pozner, J-E. 2010. "Organizations gone wild: The causes, processes, and consequences of organizational misconduct." The Academy of Management Annals, 4: 53-107.

Hadfield, Gillian K. 2005. "Exploring Economic and Democratic Theories of Civil Litigation: Differences Between Individual and Organizational Litigants in the Disposition of Federal Civil Cases." Stanford Law Review:1275-1327.

Hahl, Oliver and Ezra W Zuckerman. 2014. "The Denigration of Heroes? How the Status Attainment Process Shapes Attributions of Considerateness and Authenticity1." American Journal of Sociology 120:504-554.

Harrison, SH, Ashforth, BE, Corley, KG. 2009. "Organizational sacralization and sacrilege." Research in Organizational Behavior, 29: 225-254.

Heinz, John P and Edward O Laumann. 1982. Chicago lawyers: The social structure of the bar: Russell Sage Foundation.

Hirsh, C Elizabeth. 2009. "The strength of weak enforcement: The impact of discrimination charges, legal environments, and organizational conditions on workplace segregation." American Sociological Review 74:245-271.

Jensen, M. 2006. "Should we stay or should we go? Accountability, status anxiety, and client defections." Administrative Science Quarterly, 51: 97-128.

Jonsson, S, Greve, H.R, Fujiwara-Greve, T. 2009. “Undeserved loss: The spread of legitimacy loss to innocent organizations in response to reported corporate deviance." Administrative Science Quarterly, 54: 195-228.

Kahneman, D, Schkade, D, Sunstein, CR. 1998. "Shared outrage and erratic awards: The psychology of punitive damages" Journal of Risk and Uncertainty, 16: 49-86.

Kalev, Alexandra and Frank Dobbin. 2006. "Enforcement of civil rights law in private workplaces: The effects of compliance reviews and lawsuits over time." Law \& Social Inquiry 31:855-903.

Kenworthy, Lane, Stewart Macaulay, and Joel Rogers. 1996. "“The More Things Change...": Business Litigation and Governance in the American Automobile Industry." Law \& Social Inquiry 21:631-678.

Kim, Jerry W. 2012. "Arbiter of science: Institutionalization and status effects in FDA drug review 1990-2004." Strategic Organization 10:128-157. 
Kim, Jerry W and Brayden G King. 2014. "Seeing stars: Matthew effects and status bias in Major League Baseball umpiring." Management Science 60:2619-2644.

King, BG. 2008. "A Political Mediation Model of Corporate Response to Social Movement Activism.” Administrative Science Quarterly, 53: 395-421.

King, BG, Whetten, DA. 2008. "Rethinking the relationship between reputation and legitimacy: A social actor conceptualization." Corporate Reputation Review, 11(3): 192-207.

King, BG. 2011. "The tactical disruptiveness of social movements: Sources of market and mediated disruption in corporate boycotts." Social Problems, 58(4): 491-517.

King, BG, McDonnell, M-H. 2014. "Good firms, good targets: The relationship between corporate social responsibility, reputation, and activist targeting." In Corporate Social Responsibility in a Globalizing World, Kiyoteru Tsutsui (ed.), Cambridge, UK: Cambridge University Press.

Klein, J, Dawar, N. 2004. "Corporate social responsibility and consumers' attributions and brand evaluations in a product-harm crisis." International Journal of Research in Marketing, 21: 203-217.

Koehler, JJ, Gershoff, AD. 2003. "Betrayal aversion: When agents of protection become agents of harm." Organizational Behavior and Human Decision Processes, 90: 244-261.

Kovács, Balázs and Amanda J Sharkey. 2014. "The paradox of publicity how awards can negatively affect the evaluation of quality." Administrative Science Quarterly 59:1-33.

Kunda, Z. 1987. "Motivated inference: Self-serving generation and evaluation of causal theories." Journal of Personality and Social Psychology, 53: 636.

Lang, G.E. and K. Lang. 1988. "Recognition and renown: The survival of artistic reputation." American Journal of Sociology, 79-109.

Lange, D., Lee, PM, Dai, Y. 2011. “Organizational reputation: a review.” Journal of Management, 37(1)153-184.

Leiblein, M.J, Reuer, JJ, Dalsace, F. 2002. "Do make or buy decisions matter? The influence of organizational governance on technological performance." Strategic Management Journal, 22: 317-333.

Love, EG, Kraatz, M. 2009. "Character, conformity, or the bottom line? How and why downsizing affected corporate reputation.” Academy of Management Journal, 52(2): 314-335.

Malmendier, U., \& Tate, G. 2009. "Superstar CEO's." Quarterly Journal of Economics, 124(4): 1593-1638. 
McDonnell, M-H, King, BG. 2013. "Keeping up appearances: Reputational threat and impression management after social movement boycotts." Administrative Science Quarterly, 58: 387-419.

McDonnell, M-H, Werner, T. 2016. "Blacklisted businesses: Social activist challenges and the disruption of corporate political activity." Administrative Science Quarterly, 61: 584-620.

Merton, RK. 1968. “The Matthew effect in science.” Science, 159(3810): 56-63.

Mishina, Y, Dykes, BJ, Block, ES, Pollock, TJ. 2010. "Why 'good' firms do bad things: The effects of high aspirations, high expectations, and prominence on the incidence of corporate illegality." Academy of Management Journal, 53: 701-722.

Mizruchi, Mark S. 2013. The Fracturing of the American Corporate Elite: Harvard University Press.

Mizruchi, Mark S. 2004. "Berle and Means revisited: The governance and power of large US corporations." Theory and Society 33:579-617.

Nadler, J, McDonnell, M-H. 2011. "Moral character, motive, and the psychology of blame." Cornell Law Review, 97: 255-304.

Nielsen, Laura Beth, Robert L Nelson, and Ryon Lancaster. 2010. "Individual justice or collective legal mobilization? Employment discrimination litigation in the post civil rights United States." Journal of Empirical Legal Studies 7:175-201.

Nelson, Robert L, Ellen C Berrey, and Laura Beth Nielsen. 2008. "Divergent paths: Conflicting conceptions of employment discrimination in law and the social sciences." Annual Review of Law and Social Science 4:103-122.

Nordgren, L, McDonnell, M-H. 2010. "The scope-severity paradox: Why doing more harm is judged to be less harmful." Social Psychological and Personality Science, 2: 97-102.

O’Donnell, E. and Schultz, JJ. Jr. 2005. "The halo effect in business risk audits: Can strategic risk assessment bias auditor judgment about accounting detail?" The Accounting Review, 80: 921-939.

Peterson, Richard A and Narasimhan Anand. 2004. "The production of culture perspective." Annual review of sociology:311-334.

Podolny, J. M. 1994. "Market Uncertainty and the Social Character of Economic Exchange." Administrative Science Quarterly 39:458-483.

Podolny, JM. 2001. "Networks as pipes and prisms of the market." American Journal of Sociology, 102: 33-60. 
Pollock, TG, Rindova, VP, Maggitti, PG. 2008. "Market watch: Information and availability cascades among the media and investors in the U.S. IPO market." Academy of Management Journal, 51: 335-358.

Rachlinski, JJ et al. 2009. "Does unconscious racial bias affect trial judges? Notre Dame Law Review, 84: 1195.

Rao H. 1994. "The social construction of reputation: Certification contests, legitimation, and the survival of organizations in the American automobile industry: 1895-1912." Strategic Management Journal, 15: 29-44.

Raub, W, Weesie J. 1990. "Reputation and efficiency in social interactions: An example of network effects." American Journal of Sociology, 96: 626-654.

Rhee M, Haunschild P. 2006. "The liability of a good reputation: A study of product recalls in the U.S. automobile industry." Organization Science, 17: 101-117.

Ridgeway C. 1991. "The social construction of status value: Gender and other nominal characteristics." Social Forces, 70(2) 367-386.

Rindova VP, Petkova AP, Kotha S. 2007. "Standing out: How new firms in emerging markets build reputation." Strategic Organization, 5(1) 31-70.

Rindova VP, Williamson IO, Petkova AP. 2010. "Reputation as an intangible asset: Reflections on theory and methods in two empirical studies of business school reputations." Journal of Management, 36(3): 610-619.

Rindova, VP, Williamson, IO, Petkova, AP, Sever, JM. 2005. "Being good or being known: An empirical examination of the dimensions, antecedents, and consequences of organizational reputation." Academy of Management Journal, 48(6): 1033-1049.

Roberts, PW, Dowling, GR. 2002. “Corporate reputation and sustained superior financial performance." Strategic Management Journal, 23: 1077-1093.

Rosoff, SM. 1989. "Physicians as criminal defendants: Specialty, sanctions, and status liability." Law and Human Behavior, 13: 231-236.

Selmi, Michael. 2000. "Why are employment discrimination cases so hard to win." La. L. Rev. 61:555.

Shaffer, Gregory. 2009. "How Business Shapes Law: A Socio-Legal Framework." Connecticut Law Review 42:147.

Sharkey, Amanda J. 2014. "Categories and Organizational Status: The Role of Industry Status in the Response to Organizational Deviance1." American Journal of Sociology 119:1380-1433. 
Sine, WD, Shane, S, Di Gregorio, D. 2003. "The halo effect and technology licensing: The influence of institutional prestige on the licensing of university inventions." Management Science, 49(4): 478-496.

Skolnick, P, Shaw, JI (1994) "Is defendant status a liability or a shield? Crime severity and professional relatedness.” Journal of Applied Social Psychology, 24: 1827-1836.

Sorenson, O. 2014. "Status and reputation: Synonyms or separate concepts?" Strategic Organization, 12: 62-69.

Staw, BM, Epstein, LD. 2000. "What bandwagons bring: Effects of popular management techniques on corporate performance, reputation and CEO pay." Administrative Science Quarterly, 45: 523-556.

Stern, I, Dukerich, JM, Zajac, E. 2013. "Unmixed signals: How reputation and status affect alliance formation." Strategic Management Quarterly, 35: 512-531.

Stuart, TE., Hoang, H, Hybels, RC. 1999. "Interorganizational endorsements and the performance of entrepreneurial ventures.” Administrative Science Quarterly, 44: 315-349.

Sutherland, Edwin Hardin. 1949. White collar crime. New York: Dryden Press.

Sutton, JR, Dobbin, F, Meyer, JW, Scott, WR. 1994. "The legalization of the workplace." The American Journal of Sociology, 99: 944-971.

Thye, Shane R. 2000. "A status value theory of power in exchange relations." American Sociological Review 65:407-432.

Traut-Mattausch, E, Schulz-Hardt, S, Greitemeyer, T., and Frey, D. (2004) "Expectancy confirmation in spite of disconfirming evidence: The case of price increases due to the introduction of the Euro.” European Journal of Social Psychology, 34: 739-760.

Ulmer, RR. 2001. "Effective crisis management through established stakeholder relations at Malden Mills as a case study." Management Communication Quarterly, 14: 590-615.

USEEOC. 2013. "Charge statistics: FY 1997 through FY 2012." Available at http://www.eeoc.gov/eeoc/statistics/enforcement/charges.cfm. Last accessed October 26, 2013.

Useem, Michael. 1984. The inner circle, vol. 617: New York: Oxford University Press.

Wagner, David G and Joseph Berger. 2002. "Expectation states theory: An evolving research program." New directions in contemporary sociological theory 41.

Waguespack, DM and Sorenson, O. 2011. "The ratings game: Asymmetry in classification." Organization Science 22:541-553. 
Washington, M, Zajac EJ. 2005. "Status evolution and competition: Theory and evidence." Academy of Management Journal, 48(2): 282-296.

Weigelt, K, Camerer, C. 1988. "Reputation and corporate strategy: A review of recent theory and applications." Strategic Management Journal, 9(5): 443-454.

Wheeler, S., D. Weisburd and N. Bode. 1982. "Sentencing the white-collar offender: Rhetoric and reality." American Sociological Review, 47: 641-59. 